\title{
Removal of waterborne bacteria from surface water and groundwater by cost-effective household water treatment systems (HWTS): A sustainable solution for improving water quality in rural communities of Africa
}

\author{
Jocelyne K Mwabi', Bhekie B Mamba² and Maggy NB Momba'* \\ 'Department of Environmental, Water and Earth Science, Tshwane University of Technology, 175 Nelson Mandela Drive, Pretoria 0002, South Africa \\ 2Department of Applied Chemistry, University of Johannesburg, PO Box 17011, Doornfontein 2028, South Africa
}

\begin{abstract}
In this study 5 household water-treatment devices/systems (HWTS) were constructed using inexpensive local materials (sand, gravel, zeolites and clays). They included the silver-impregnated porous pot filter (SIPP), the ceramic candle filter (CCF), the conventional biosand filter (BSF-S), a modified biosand filter with zeolites (BSF-Z), and a bucket filter (BF). Their ability to remove turbidity and pathogenic bacteria (Vibrio cholerae, Salmonella typhimurium and Shigella dysenteriae) from synthetic sterile water, groundwater and surface-water sources was evaluated. The flow rates ranged from $0.05 \mathrm{l} \cdot \mathrm{h}^{-1}$ to $2.49 \mathrm{l} \cdot \mathrm{h}^{-1}$ for SIPP; $1 \mathrm{l} \cdot \mathrm{h}^{-1}$ to $4 \mathrm{l} \cdot \mathrm{h}^{-1}$ for CCF; $0.81 \mathrm{\ell} \cdot \mathrm{h}^{-1}$ to $6.84 \mathrm{l} \cdot \mathrm{h}^{-1}$ for BSF-S; $1.74 \mathrm{l} \cdot \mathrm{h}^{-1}$ to $19.2 \mathrm{l} \cdot \mathrm{h}^{-1}$ for BSF-Z; and from $106.5 \mathrm{l} \cdot \mathrm{h}^{-1}$ to $160.5 \mathrm{l} \cdot \mathrm{h}^{-1}$ for BF. The highest (64\% to $98 \%$ (0.74 to $\left.1.08 \mathrm{NTU}\right)$ ) and lowest (14\% to $76 \%$ (2.91 to $\left.7.19 \mathrm{NTU}\right)$ ) average percentage turbidity removals were noted for SIPP and BF, respectively. The SIPP was the only device that consistently removed $100 \%$ of all target pathogens throughout the study. Its performance was found to be significantly superior $(p<0.05)$ compared to that of the other four devices. Sixty (60\%) to 100\% bacterial removals were observed for BSF-S; $90 \%$ to $100 \%$ for BSF-Z; $90 \%$ to $100 \%$ for CCF; and $40 \%$ to $99.9 \%$ for BF. Based on the findings of this study the SIPP can be recommended for use by rural communities as it consistently produced high-quality water that complied with the SANS 241 turbidity and microbiological limits for drinking water.
\end{abstract}

Keywords: safe drinking water, household water treatment, waterborne pathogens

\section{INTRODUCTION}

In 2008, the World Health Organisation reported the percentage of rural populations within some African countries still using unimproved water sources. These were reported to be $72 \%$ for the Democratic Republic of Congo, $71 \%$ for Madagascar and Mozambique, 62\% for Angola, 55\% for Tanzania, 54\% for Zambia, 28\% for Zimbabwe, 23\% for Malawi, $19 \%$ for Lesotho, 14\% for Swaziland, 12\% for Namibia and $10 \%$ for Botswana (WHO/UNICEF, 2010). In South Africa, the supply of safe drinking water to rural and urban populations has improved from 59\% in 1994 to $97 \%$ in 2010. According to statistics released in 2010, about 1.65 million out of 49 million people in South Africa do not have access to a safe water supply. The Department of Water Affairs is therefore seeking simple and appropriate water treatment technology options by means of which the $3 \%$ of the population in need of safe drinking water can treat the water sources that are available to them (DWA, 2010).

A number of studies have suggested that the key to reducing or even eradicating the burden of waterborne disease is through appropriate sanitation facilities and piped water systems. These could take decades to be established, especially in impoverished rural communities of African countries. Various point-of-use (POU) water treatment methods, which include biosand and

\footnotetext{
To whom all correspondence should be addressed.

표 +27 12 382-6365; Fax: +27 12 382-6354;

e-mail: mombamnb@tut.ac.za

Received 22 March 2012; accepted in revised form 24 June 2013.
}

ceramic filtration, appropriate chemical disinfection (e.g. the use of disinfectants such as chlorine and iodine), solar disinfection and natural water purifiers (e.g. Moringa oleifera) have been reported to improve the microbial quality of drinking water as well as to decrease the incidence of endemic diarrhoea caused by waterborne pathogens (Murcott, 2006). Household water treatment may provide African governments with a quick short-term solution to ensuring that all their people, especially those in rural areas, have access to safe drinking water (Sobsey, 2002). Due to the low cost of manufacturing the filters using locally available materials and the simplicity and ease of construction and maintenance, POU water-treatment systems enable users to have potable water available almost immediately after installation (Mol, 2001).

By using a list of selection and evaluation criteria, 5 household water treatment systems (HWTS) were chosen for this study from a wide range of water treatment filters. The selected devices were the silver-impregnated porous pot filter (SIPP), the ceramic candle filter (CCF), the conventional biosand filter (BSF-S), a modified biosand filter with zeolites (BSF-Z), and a bucket filter (BF). The main idea in constructing these filters was to evaluate the effect of flow rate and the presence of the biological layer and clay materials with or without silver on the reduction of microbial contaminants and turbidity. The BSF and the BSF-Z are both slow sand filters while the $\mathrm{BF}$ is a fast or rapid sand filter, but all three use sand as the filtering media. While both BSF-S and BSF-Z have a biological layer, which is absent in the BF, the BSF-Z has an additional zeolite layer. The CCF and the SIPP devices differed from these three filters since they have clay material and not 
sand as filter medium. This study therefore focused on comparing these selected filters for the removal of turbidity and pathogenic bacteria (S. dysenteriae, S. typhimurium and V. cholerae) also taking into account the flow rate of each filter.

\section{MATERIALS AND METHODS}

\section{Selection criteria}

An extensive study of the literature was undertaken and a list of more than 20 devices was proposed for evaluation. A number of selection and evaluation criteria were used to condense that list to 5 HWTS selected for this study (Mwabi et al., 2012). The purpose of these criteria was to ensure that the filters:

(i) produce water that meets the South African National Standard - SANS 241 (SABS, 2011) microbiological drinking water specification;

(ii) are easy to construct, operate and maintain;

(iii) are cost-effective by being constructed from locally available material and not running on electricity, and

(iv) are able to produce a minimum volume of $25 \ell$.person ${ }^{-1} \cdot d^{-1}$ of water as recommended by the South African Department of Water Affairs (DWAF, 2002).

\section{Construction of the household water-treatment systems/ devices (HWTS)}

All materials used in the manufacturing process of the selected devices are locally available in South Africa. These were natural resources (gravel, sand, clinoptilolite zeolite and clay) that may also be found in the immediate environment of rural communities. The use of locally available materials helps to reduce a community's dependence on outside sources and often reduces the manufacturing costs of HWTS (Murphy et al., 2009). The construction methods for these modified filters have been published by Mahlangu et al. $(2011 ; 2012)$ and Mwabi et al. $(2011 ; 2012)$ and manufacturing costs were found to be dependent on the availability and accessibility of materials locally.

\section{Silver-impregnated porous-pot filter}

The silver-impregnated porous pot filter (SIPP) was developed as part of a previous project commissioned by the Water Research Commission of South Africa (WRC Project No. K8/810; Momba et al., 2008). The SIPP (Fig. 1) was manufactured according to a method described by Momba et al. (2008). The SIPP is similar to the ceramic silver-impregnated pot filter (CSF) described by Van Halem et al. (2009), but it differs from the CSF in that it was fired after impregnating the silver nitrate instead of being coated with colloidal silver after firing as was done in the construction of the CSF. The silver was impregnated in the clay and sawdust mixture before shaping and firing the pot, to reduce leaching of the silver into treated water.
The total price for a complete SIPP filter is between ZAR240.56 and ZAR290.56.

\section{Ceramic candle filter}

A Just Water Ceramic Candle Filter was obtained from Headstream Water Holdings (South Africa). It consists of a material cover with a pore size of $5 \mu \mathrm{m}$, placed over a hollow, dome-shaped ceramic candle ( $10 \mathrm{~cm}$ x $10 \mathrm{~cm}$; height and width) which contains pores that filter particles down to $0.5 \mu \mathrm{m}$. The ceramic shell contains an activated charcoal interior medium that covers a carbon-fibre blanket at the base of the filter with pore sizes of $0.2 \mu \mathrm{m}$. The candle filter was wedged between two $25 \mathrm{l}$ buckets by inserting and attaching the candle filter through the base of the upper bucket and through the lid of the bottom bucket, as well as inserting a spigot $5 \mathrm{~cm}$ from the base of the lower bucket, as illustrated in Fig. 2a-b. The total manufacturing cost amounted to ZAR501.15.

\section{Biosand filter}

Two types of plastic biosand filters were constructed in the workshop of the Tshwane University of Technology, Pretoria, South Africa, with some modifications to the biosand filter design developed by David Manz at the University of Calgary, Canada, in the early 1900s (Buzunis, 1995). Briefly, two modifications were made to the original design, (i) an adjustment to the height and width of the filter (41 cm high, $32 \mathrm{~cm}$ wide); and (ii) the replacement of the fine sand with clinoptilolite zeolite to serve as filter media (BSF-Z). The filter size was scaled down and a $25 \ell$ plastic bucket was used to ensure that 

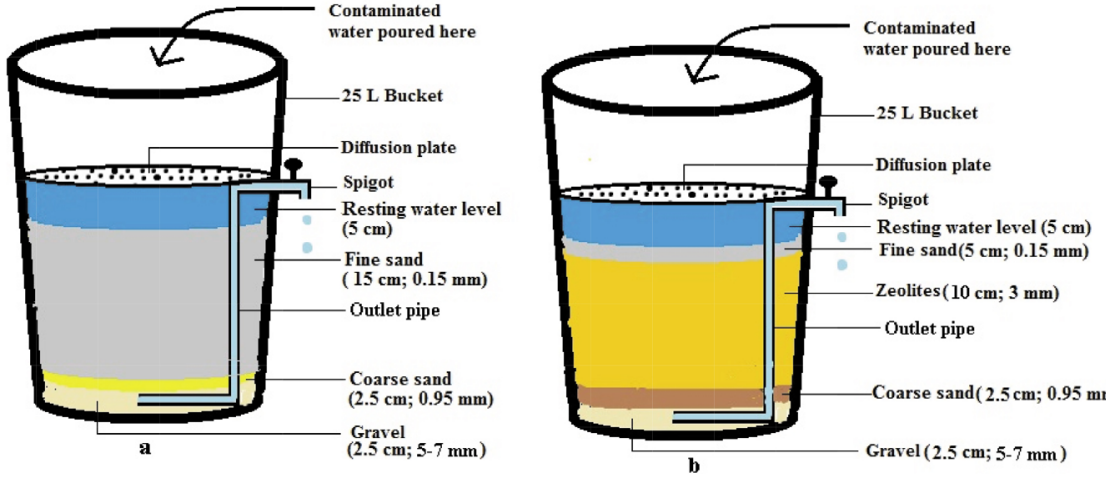

Figure 3

Schematic diagram of plastic biosand filters; (a) biosand filter-standard (BSF-S); and (b) biosand filter-zeolite (BSF-Z)

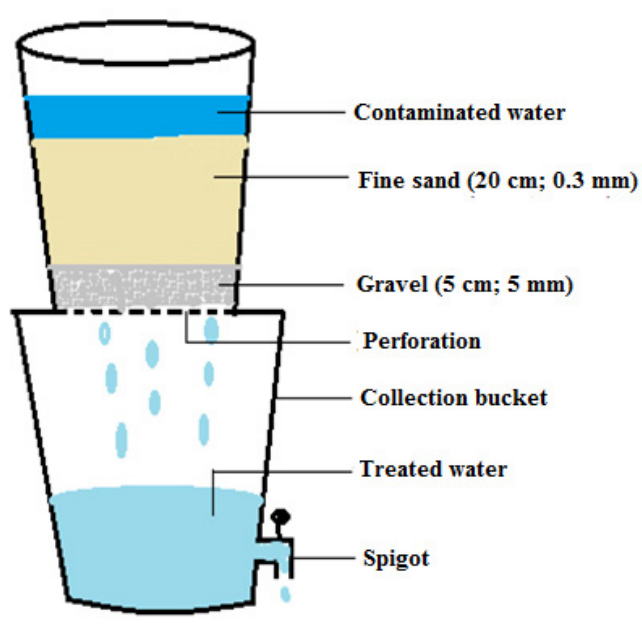

a

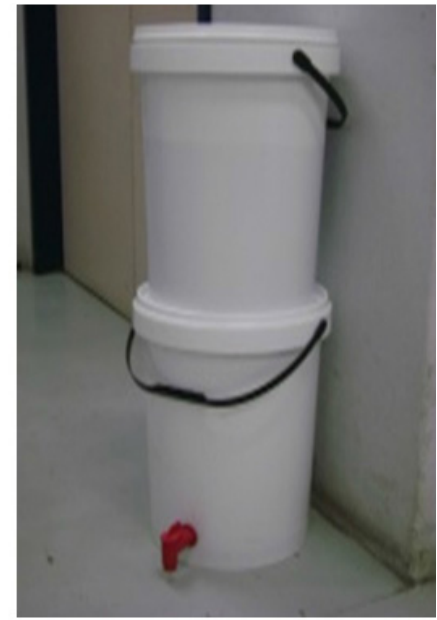

b
Figure 4

(a) Schematic diagram; and (b) photograph of the bucket filter (BF) pathogenic bacteria was conducted simultaneously. The findings for removal of indicator bacteria have been published elsewhere (Mwabi et al., 2012).

\section{Preparation of synthetic water sample}

Bacterial strains of Salmonella typhimurium ATCC 14028 were obtained from the American Type Culture Collection (Quantum Biotechnologies, RSA) and those of Shigella dysenteriae and Vibrio cholerae from the stock cultures of the CSIR in Pretoria, South Africa. These strains were confirmed by cultural tests using selective agar media, according to the methods prescribed by Environment Agency (2002; 2006) and APHA (2005).

For each test bacterium, $1 \mathrm{m \ell}$ of an overnight culture was serially diluted in $9 \mathrm{~m} \ell$ sterile physiological water $(0.9 \% \mathrm{w} / \mathrm{v} \mathrm{NaCl})$ and spreadplated onto selective agar plates. Plates were incubated at $36^{\circ} \mathrm{C} \pm 1^{\circ} \mathrm{C}$ for $24 \mathrm{~h}$ and the resulting colonies were counted to express the initial bacterial concentrations as $\mathrm{CFU} \cdot \mathrm{m} \ell^{-1}$. The aliquots of the overnight cultures corresponding to approximately $10^{6}$ $\mathrm{CFU} \cdot \mathrm{m} \ell^{-1}$ were inoculated into a $20 \ell$ final volume of sterile normal saline water $(0.9 \% \mathrm{w} / \mathrm{v})$. The spiked water samples were shaken vigorously several times before being passed through the filtering devices. the filter would occupy only a small area of a rural home. The clinoptilolite zeolite was used because a number of studies have shown that zeolites have high removal efficiencies of chemical contaminants and indicator bacteria in wastewater (Misaelides, 2011). This modification aimed to determine whether the added zeolite would enhance the performance of a biosand filter. The formation of a biolayer is the key component of the biosand filter for removal of pathogens. CAWST (2010) recommends up to 30 days for the biolayer to fully form. The construction of these two biosand filters has been described by Mahlangu et al., (2011) and illustrated in Fig. 3. The total manufacturing cost of the two biological filters amounted to ZAR133.16 for BSF-S and ZAR164.23 for the BSF-Z filter.

\section{The bucket filter}

The bucket filter was also constructed in the workshop of the Tshwane University of Technology (Mahlangu et al., 2012). It was made of two $25 \ell$ plastic buckets mounted on top of each other (Fig. 4). The top bucket contained the filter media while the lower bucket collected and temporarily stored the filtered water. The total manufacturing cost amounted to ZAR149.18.

\section{Evaluation of the performance of the devices}

The performance of the selected home water treatment devices in removing indicator bacteria (E. coli; faecal coliforms) and

\section{Environmental water sources}

Source water samples were collected 6 times from each of 4 different sites in Gauteng Province, South Africa, between 27 September 2010 and 18 March 2011. Surface water samples of low (SWL) and high (SWH) turbidity were collected from the Apies River (Pretoria) and from Hartbeespoort Dam (Hartbeespoort, North West Province), respectively. Groundwater samples with low (GWL) and high (GWH) turbidity were collected from boreholes in Delmas (on the border of the Mpumalanga and Gauteng Provinces) and Wallmannsthal (Gauteng Province), respectively. In this study the raw water was classified according to the turbidity level and was defined as follows: 2 NTU to $18 \mathrm{NTU}=\mathrm{SWL}, 10 \mathrm{NTU}$ to $40 \mathrm{NTU}=\mathrm{SWH}, 2 \mathrm{NTU}$ to $10 \mathrm{NTU}=\mathrm{GWL}$ and $2 \mathrm{NTU}$ to $15 \mathrm{NTU}=\mathrm{GWH}$. The water samples were collected in sterile plastic containers and transported to the laboratory. During the study period, S. typhimurium, V. cholerae and S. dysenteriae were not detected in groundwater samples and the reference bacterial strains were spiked into these water sources following the same procedure mentioned in the preparation of synthetic water samples.

\section{Operation of the devices}

Source-water samples were filtered through each device in the laboratory as follows: $5 \ell \cdot \mathrm{d}^{-1}$ for SIPP and $20 \ell \cdot \mathrm{d}^{-1}$ for each of the remaining HWTS devices. Different volumes of filtrates were 
collected at $1 \mathrm{~h}$ intervals over the $3 \mathrm{~h}$ period of filtration, with the assumption that enough purified water would have been produced in this period for drinking and cooking. One unit of each type of filter was used for the duration of this study.

\section{Flow-rate analysis}

The flow rates of the SIPP, CCF and BSF-S were measured by recording the volume of water collected in $1 \mathrm{~h}$, over a period of $3 \mathrm{~h}$, to obtain a triplicate reading. For the BSF-Z, the flow rate was measured by recording the volume of water collected in $1 \mathrm{~min}$, immediately after the water had been poured into the filter; this was done at hourly intervals over $3 \mathrm{~h}$. For the BF, it was measured by recording the time it took to filter $20 \ell$ of water. Flow rate was recorded as litres per hour $\left(\ell \cdot h^{-1}\right)$ in this study.

\section{Turbidity removal by HWTS devices}

A turbidity meter (Eutech, RSA) was used to determine the level of turbidity in water samples before and after filtration. Readings for each sample were taken in triplicate. The percentage turbidity reduction achieved by each of the filter devices was calculated using the following equation:

$$
\% \text { turbidity reduction }=\frac{\text { turbidity } \left._{\text {unfiltered }}-\text { turbidity }_{\text {filtered }}\right)}{\left(\text { turbidity }_{\text {unfiltered }}\right)} \times 100
$$

\section{Performance of the HWTS in removing waterborne bacteria}

The presence/absence of the target organisms was detected before and after treatment of the environmental water samples. With some modifications, standard methods (Environmental Agency (2002; 2006), which included pre-enrichment steps and streak plate techniques, were used for the isolation and detection of these organisms. For Salmonella spp. and Shigella spp., filtration of $500 \mathrm{~m} \ell$ of water sample through sterile $47 \mathrm{~mm}$ diameter membranes of $0.45 \mu \mathrm{m}$ pore size (Millipore) was followed by the immersion of these membranes in $50 \mathrm{ml}$ sterile brain-heart infusion broth (Merck, SA) and incubation at $36^{\circ} \mathrm{C} \pm 1^{\circ} \mathrm{C}$ for $6-8 \mathrm{~h}$. For Vibrio spp., a similar pre-enrichment method was used with the exception that the membranes were immersed in $100 \mathrm{~m} \ell$ double-strength alkaline peptone water ( $\mathrm{pH}$ 8.5). Serial dilution of the pre-enriched suspensions and selective culture media ((xylose lysine deoxycholate agar (XLD) and/or Salmonella-Shigella agar (SS) and thiosulfate citrate bile sucrose (TCBS) agar (Merck, SA)) were used for the detection the target organisms as described by standard methods.

Bacterial counts in spiked water samples were calculated and expressed in $\log _{10}$ units. The $\log _{10}$ bacterial reduction and percentage removal efficiencies (Brözel and Cloete, 1991) were calculated using the following formula:

$$
\begin{array}{r}
\text { Log reduction }=\left(\begin{array}{l}
\log _{10} \text { bacterial count before filtration } \\
\left.-\log _{10} \text { bacterial count } \text { after filtration }\right)
\end{array}\right. \\
\% \text { Removal }=100-\frac{\text { Survival count }}{\text { Initial count }} \times 100
\end{array}
$$

Following the isolation and detection of organisms, 5 characteristic colonies for presumptive Salmonella spp., Shigella spp. and Vibrio spp. were randomly selected from different plates for each water sample, transferred onto the selective media by the streak-plate method and incubated at $36^{\circ} \mathrm{C} \pm 1^{\circ} \mathrm{C}$ for $24 \mathrm{~h}$. The colonies were further purified by the same methods at least
3 times using nutrient agar (Biolab), and submitted to Gram staining, oxidase test and the API 20E identification systems (bioMérieux, Marcy-l'Etoile, France). Colonies of each target bacterium presumptively identified and confirmed to be positive by the API $20 \mathrm{E}$ identification system were sub-cultured onto their respective selective media 3 times before being used for molecular identification.

Two hundred microliter $(200 \mu \ell)$ of an overnight culture of each target bacterial strain was suspended in sterile Milli- $Q$ water and the genomic DNA was extracted using the ZR Fungal/ Bacterial DNA Kit (ZYMO Research, Pretoria, South Africa) according to the procedures provided by the manufacturer. Species-specific primers were used for the amplification of a specific target gene associated with each target pathogenic bacterium. The $i p a H$ gene encoding for the invasion plasmid antigen $\mathrm{H}$ was used to detect $S$. dysenteriae. The ipaB gene encoding for the invasion plasmid antigen $B$ was used to detect S. typhimurium and the EspM gene encoding for a component of the cytoplasmic membrane protein of $V$. cholerae was used to identify Vibrio spp. Primers used in this study were synthesised by Inqaba Biotechnical Industries (Pty) Ltd, Pretoria, South Africa.

The PCR amplification of the target bacterial DNA was carried out in a thermal cycler (MJ Mini ${ }^{\mathrm{TM}}$ Personal Thermal Cycler, Biorad) using $200 \mu \ell$ PCR tubes and a reaction mixture volume of $50 \mu \ell$ containing $10 \mathrm{ng}$ to $20 \mathrm{ng}$ of template DNA, $25 \mu \ell 2$ X Dream Taq ${ }^{\mathrm{TM}}$ PCR master mix (10X Dream Taq ${ }^{\mathrm{TM}}$ buffer, $2 \mu \mathrm{M}$ dnTP mix and $1.25 \mathrm{u}$ Dream Taq ${ }^{\mathrm{TM}}$ polymerase) and a $10 \mu \mathrm{M}$ concentration of each PCR primer and then made up to $50 \mu \mathrm{l}$ with ultra-pure nuclease-free water. The cycling conditions used by previous investigators were followed after standardisation in our laboratory. For the amplification of target genes of $S$. dysenteriae, $S$. typhimurium and $V$. cholerae the cycling parameters described by Thiem et al. (2004), Kong et al. (2002) and Momba et al. ( 2006) were followed, respectively. An aliquot of $10 \mu \ell$ of PCR product was electrophoresed through a $1.5 \%$ agarose $(w / v)$ gel (Merck, RSA) in $1 \mathrm{U}$ TAE buffer (40 mM Tris-HCl, 20mM Na-acetate, 1 mM EDTA, pH 8.5 , Biorad) and stained with $0.5 \mu \mathrm{g} \cdot \mathrm{m} \ell^{-1}$ ethidium bromide (EtBr, Merck). The amplified product was visualised under UV light in an InGenius L Gel documentation system (Syngene, Vacutec RSA). A 100-bp ladder (Fermentas, supplied by InqabaBiotec SA) was included on each gel as a molecular size standard. The electrophoresis was carried out at $80 \mathrm{~V}$ for $30 \mathrm{~min}$. A negative control consisted of all PCR reagents except for the template DNA and a positive control having genomic DNA of the reference strains was also included in each PCR run.

\section{Leaching of silver ions in water filtered by SIPP}

The preliminary experimental studies to determine the amount of silver ions leached out by the SIPP during filtration of water were conducted by Momba and co-authors (2010b). The authors conducted a series of analytical and mechanical characterisation tests on the SIPP, which included the XRF analysis that confirmed the presence of Ag, the breaking strength and the porosity of the filter. It was found that the silver leached from the SIPP filter at concentrations ranging between $0.5 \mathrm{mg} \cdot \ell^{-1}$ and $0.6 \mathrm{mg} \cdot \ell^{-1}$. The Ag elution was greater in the early stages (within the first $5 \ell$ ) but appeared to begin to stabilise after filtering a total volume of $10 \ell$ intake water.

For the present study, the amount of silver leached by SIPP was measured at the end of the study after a total volume of $305 \mathrm{l}$ had been filtered, to determine whether leaching of silver 


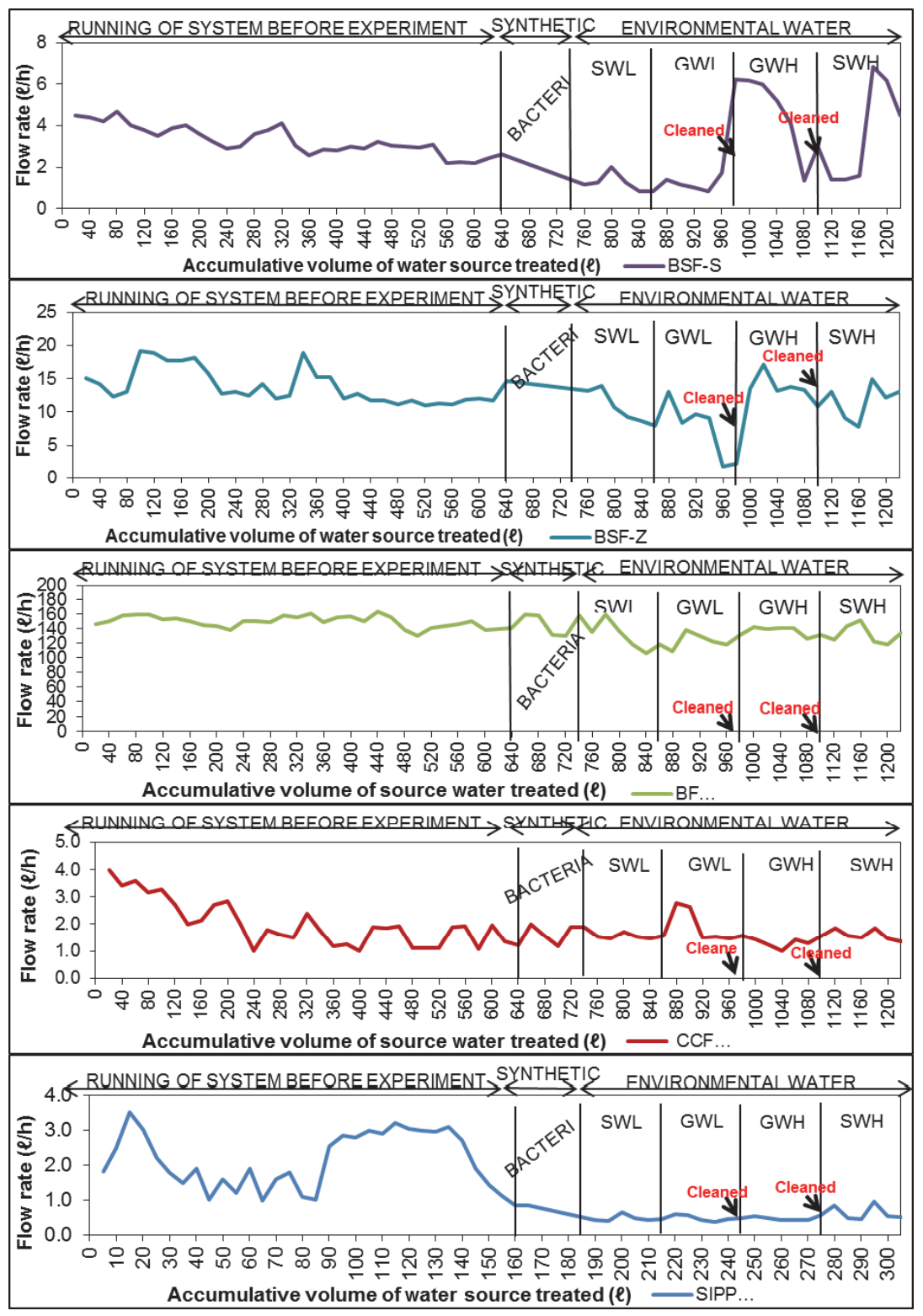

Figure 5

Flow rates of selected devices: (a) SIPP; (b) CCF; (c) $B S F-S$; (d) BSF-Z; and (e) BF (SWL-surface water of low turbidity (SWH - surface water of high turbidity; GWL - groundwater of low turbidity; and GWH - groundwater of high turbidity)

was reduced over time, by comparing the results obtained to the initial results of Momba et al. (2010b). Briefly, the SIPP filter was soaked in $20 \mathrm{l}$ of deionised water overnight prior to use. The concentration of the silver in the filtered water was monitored at $1 \mathrm{~h}$ intervals over a $3 \mathrm{~h}$ period. The first, second and third filter runs were performed with deionised water, groundwater and surface water, respectively. The Spectro Acros ICP spectrometer (Spectro, RSA) was used to detect and determine the concentration of silver in each water sample. A silver standard was prepared from a solution of silver nitrate (Merck, $\mathrm{RSA}$,) according to the manufacturers' instructions.

\section{Statistical analysis}

Data used to assess for water quality before and after treatment through each selected device were subjected to one-way analysis of variance (ANOVA) to compare more than two groups. Comparisons were made between the treatment means of each device per water source to determine if there were significant differences between treatments. Where differences were observed, pair-wise comparisons or post hoc tests were performed and the Wilcoxon Rank-Sum Test was used to compare the two groups. The interpretation was performed at the $95 \%$ confidence limit.

\section{RESULTS AND DISCUSSION}

The quantity of water produced by household water-treatment systems is important, as each of these systems must be able to produce the minimum quantity of potable water of $25 \ell \cdot$ person $^{-1} \cdot \mathrm{d}^{-1}$ for basic human activities, as prescribed by the Regulations under Section 9 of the Water Services Act (No. 108 of 1997) of South Africa; Norms and Standards for Quality Water Services (DWAF, 2002). The HWTS used in this study could all produce the requisite $25 \ell \cdot$ person $^{-1} \cdot \mathrm{d}^{-1}$ (Fig. 5a-e). The average flow rates obtained ranged from $0.05 \ell \cdot h^{-1}$ to $2.49 \ell \cdot h^{-1}$ for SIPP; from $1 \ell \cdot h^{-1}$ to $4 \ell \cdot h^{-1}$ for CCF; from $0.81 \mathrm{l} \cdot \mathrm{h}^{-1}$ to $6.84 \mathrm{\ell} \cdot \mathrm{h}^{-1}$ for BSF-S; from $1.74 \mathrm{l} \cdot \mathrm{h}^{-1}$ to $19.2 \mathrm{l} \cdot \mathrm{h}^{-1}$ for BSF-Z; and from $106.5 \ell \cdot h^{-1}$ to $160.5 \ell \cdot h^{-1}$ for BF (Fig. 5). The flow rates of the selected devices were similar to those reported for commonly distributed HWTS in developing countries, which ranged between $10 \mathrm{l} \cdot \mathrm{h}^{-1}$ and $60 \mathrm{l} \cdot \mathrm{h}^{-1}$ for biosand filters (Elliott 


\begin{tabular}{|c|c|c|c|c|c|c|}
\hline \multicolumn{7}{|c|}{$\begin{array}{c}\text { TABLE } 1 \\
\text { Average }( \pm \text { SD) turbidity (NTU) reduction by HWTS devices, } n=18\end{array}$} \\
\hline $\begin{array}{l}\text { Water } \\
\text { source }\end{array}$ & $\begin{array}{l}\text { Before } \\
\text { treatment }\end{array}$ & $\begin{array}{l}1 \mathrm{~h} \text { after } \\
\text { treatment }\end{array}$ & $\begin{array}{l}2 \mathrm{~h} \text { after } \\
\text { treatment }\end{array}$ & $\begin{array}{l}3 \mathrm{~h} \text { after } \\
\text { treatment }\end{array}$ & Overall average & $\begin{array}{l}\text { \% removal } \\
\text { efficiency }\end{array}$ \\
\hline \multicolumn{7}{|c|}{ Silver-impregnated porous pot (SIPP) } \\
\hline SWL & $11.93 \pm 10.24$ & $1.34 \pm 0.60$ & $1.01 \pm 0.40$ & $0.89 \pm 0.44$ & $1.08 \pm 0.51$ & 91 \\
\hline SWH & $40.4 \pm 4.13$ & $0.86 \pm 0.42$ & $0.78 \pm 35$ & $0.58 \pm 32$ & $0.74 \pm 14$ & 98 \\
\hline GWL & $2.17 \pm 0.86$ & $0.78 \pm 0.30$ & $0.79 \pm 0.32$ & $0.76 \pm 0.39$ & $0.78 \pm 0.33$ & 64 \\
\hline GWH & $8.39 \pm 5.45$ & $0.96 \pm 0.24$ & $1.01 \pm 0.69$ & $0.75 \pm 0.30$ & $0.91 \pm 0.46$ & 89 \\
\hline \multicolumn{7}{|c|}{ Ceramic candle filter (CCF) } \\
\hline SWL & $11.93 \pm 10.24$ & $0.91 \pm 0.27$ & $0.77 \pm 0.38$ & $0.61 \pm 0.16$ & $0.76 \pm 0.71$ & 94 \\
\hline SWH & $40.4 \pm 4.13$ & $7.73 \pm 2.45$ & $7.28 \pm 3.08$ & $7.69 \pm 2.67$ & $7.56 \pm 2.70$ & 81 \\
\hline GWL & $2.17 \pm 0.86$ & $1.05 \pm 0.70$ & $0.90 \pm 0.51$ & $0.75 \pm 0.45$ & $0.90 \pm 0.57$ & 58 \\
\hline GWH & $8.39 \pm 5.45$ & $2.25 \pm 0.83$ & $2.62 \pm 1.53$ & $3.10 \pm 2.40$ & $2.65 \pm 1.71$ & 68 \\
\hline \multicolumn{7}{|c|}{ Biosand filter-standard (BSF-S) } \\
\hline SWL & $11.93 \pm 10.24$ & $0.86 \pm 0.32$ & $0.82 \pm 0.52$ & $0.68 \pm 0.28$ & $0.79 \pm 0.39$ & 93 \\
\hline SWH & $40.4 \pm 4.13$ & $9.19 \pm 4.85$ & $8.61 \pm 4.96$ & $6.82 \pm 4.33$ & $8.20 \pm 4.70$ & 80 \\
\hline GWL & $2.17 \pm 0.86$ & $2.02 \pm 1.59$ & $1.66 \pm 1.26$ & $1.93 \pm 1.45$ & $1.87 \pm 1.42$ & 14 \\
\hline GWH & $8.39 \pm 5.45$ & $7.0 \pm 4.17$ & $7.34 \pm 3.75$ & $3.10 \pm 3.00$ & $7.48 \pm 3.80$ & 11 \\
\hline \multicolumn{7}{|c|}{ Biosand filter-zeolite (BSF-Z) } \\
\hline SWL & $11.93 \pm 10.24$ & $2.14 \pm 1.50$ & $0.91 \pm 0.39$ & $0.93 \pm 0.37$ & $1.33 \pm 0.49$ & 89 \\
\hline SWH & $40.4 \pm 4.13$ & $2.35 \pm 0.91$ & $2.30 \pm 0.83$ & $2.01 \pm 0.67$ & $2.22 \pm 0.81$ & 95 \\
\hline GWL & $2.17 \pm 0.86$ & $1.07 \pm 0.67$ & $1.46 \pm 0.53$ & $0.7 \pm 0.27$ & $1.07 \pm 0.33$ & 51 \\
\hline GWH & $8.39 \pm 5.45$ & $3.87 \pm 3.09$ & $6.96 \pm 5.20$ & $2.97 \pm 1.55$ & $4.6 \pm 2.99$ & 45 \\
\hline \multicolumn{7}{|c|}{ Bucket filter (BF) } \\
\hline SWL & $11.93 \pm 10.24$ & $4.03 \pm 2.48$ & $2.45 \pm 0.43$ & $2.24 \pm 0.31$ & $2.91 \pm 1.65$ & 76 \\
\hline SWH & $40.4 \pm 4.13$ & $13.8 \pm 7.73$ & $10.2 \pm 3.13$ & $9.13 \pm 2.35$ & $11 \pm 5.31$ & 73 \\
\hline GWL & $2.17 \pm 0.86$ & $0.82 \pm 0.11$ & $0.78 \pm 0.30$ & $1.03 \pm 0.89$ & $0.87 \pm 0.4$ & 59 \\
\hline GWH & $8.39 \pm 5.45$ & $7.14 \pm 5.2$ & $3.15 \pm 1.1$ & $10.64 \pm 5.3$ & $7.19 \pm 3.8$ & 14 \\
\hline
\end{tabular}

All values are average of triplicate samples presented with the \pm standard deviation (SD)

et al., 2008); between $1 \mathrm{\ell} \cdot \mathrm{h}^{-1}$ and $11 \mathrm{\ell} \cdot \mathrm{h}^{-1}$ for ceramic candle filters (Brown, 2007); and between $1 \mathrm{l} \cdot \mathrm{h}^{-1}$ and $3 \mathrm{l} \cdot \mathrm{h}^{-1}$ for clay-pot filters (Van Halem et al., 2009).

During the study period, the devices were cleaned twice, when flow rates declined to a point where the minimum required volume of $25 \ell \cdot \mathrm{p}^{-1} \cdot \mathrm{d}^{-1}$ was no longer being produced (Fig. 5). The decline in flow rates of the HWTS resulted from the accumulation of dirt and particles on the surface of the fine sand layer of the biosand filters and bucket filter (Ngai et al., 2007) or in the micro-pores of the SIPP and CCF filters (Clasen and Boisson, 2006). The first cleaning was done before filtering groundwater samples of high turbidity $(\mathrm{GWH})$ and the second cleaning was done before filtering surface-water samples of high turbidity (SWH). The biosand filters were cleaned by removing the top $1 \mathrm{~cm}$ to $2 \mathrm{~cm}$ layer of fine sand, thoroughly washing it with deionised water and thereafter replacing it in the BSF-S and BSF-Z buckets (Lea, 2008). The ceramic candle filter and silver-impregnated porous-pot filter were cleaned by scrubbing the ceramic shell and the inside of the clay pot, respectively, with a Scotch-Brite ${ }^{\text {Tw }}$ scrub pad and clean water. The cleaning of the filters assisted in regaining the flow rate as shown in Fig. $5 \mathrm{a}-\mathrm{d}$. These findings substantiate studies done by Ngai and co-authors (2007) and Low (2002), who reported that flow rates of the biosand filters and ceramic filters increased after cleaning.

Turbidity relates to the degree of microbiological and organic/inorganic chemical content as well as colloidal content of water. The turbidity level of unfiltered water from the four water sources was found to be unacceptable (Table 1,2) as none complied with the SANS 241 (SABS, 2011) turbidity limit for drinking water in South Africa, which is $<1$ NTU. After filtration of the various water sources, the turbidity ranged between 0.74 NTU and 1 NTU (64\% to $98 \%$ reduction) for SIPP; between $0.76 \mathrm{NTU}$ and $7.56 \mathrm{NTU}$ ( $58 \%$ to $94 \%$ reduction) for CCF; between $0.79 \mathrm{NTU}$ and $8.2 \mathrm{NTU}$ (11\% to $93 \%$ reduction) for BSF-S; between 1.07 NTU and 4.6 NTU (45\% to 95\% reduction) for BSF-Z; and between 0.87 NTU and 11 NTU ( $14 \%$ to $76 \%$ ) for BF (Table 1). Some of these results are similar to figures reported in the literature, as Low (2002) reported the percentage turbidity removal efficiencies to range from $83 \%$ to 99\% for ceramic silver-coated water filters. Percentage turbidity removals ranging from $88 \%$ to $99 \%$ have been also reported for ceramic candle filters (Franz, 2004), while percentage turbidity reductions ranging from $90 \%$ to $95 \%$ have been reported for biosand filters (Ngai et al., 2004). The BF showed the lowest ( $14 \%$ to $76 \%)$ turbidity removal efficiency throughout the study, which was attributed to its high flow rate. Previous studies have shown that high flow rates do not allow enough retention/contact time between the contaminated water and the filter media, consequently reducing the efficiency of the sand media to trap particles (Ngai et al., 2004). It is important to ensure that each filter removes the maximum level of turbidity so that it may provide high-quality drinking water that complies with the SANS 241 (SABS, 2011) turbidity limit.

The main objective of this study was to remove and/or inactivate specific diarrhoeagenic bacteria from water samples. A mentioned above, no presumptive Shigella, Salmonella and Vibrio spp. were detected in groundwater source samples. 


\begin{tabular}{|c|c|c|c|c|}
\hline \multicolumn{5}{|c|}{$\begin{array}{c}\text { TABLE } 2 \\
\text { Microbial profile of water sources before filtration }\end{array}$} \\
\hline \multirow[t]{2}{*}{ Organism } & \multicolumn{4}{|c|}{$\begin{array}{c}\text { Number of samples contaminated with target pathogenic bacteria using culture } \\
\text { based methods ( } 6 \text { trials) }\end{array}$} \\
\hline & SWL* & $\mathrm{SWH}^{*}$ & GWL & GWH \\
\hline Presumptive Shigella spp. & $6(100 \%)$ & $6(100 \%)$ & 0 & 0 \\
\hline Presumptive Salmonella spp. & $6(100 \%)$ & $6(100 \%)$ & 0 & 0 \\
\hline Presumptive Vibrio spp. & $6(100 \%)$ & $6(100 \%)$ & 0 & 0 \\
\hline \multicolumn{5}{|c|}{ Average concentration of organisms spiked in synthetic and ground water sources before filtration (CFU/100 $\mathrm{m} \ell \pm \mathrm{SD}$ ) } \\
\hline Organisms & \multicolumn{2}{|c|}{$\begin{array}{c}\text { Synthetic (5 trials) } \\
\text { (Spiked sterile saline water (0.9\%)) }\end{array}$} & $\begin{array}{c}\text { GWL } \\
(6 \text { trials) }\end{array}$ & $\begin{array}{l}\text { GWH } \\
\text { (6 trials) }\end{array}$ \\
\hline S. dysenteriae & \multicolumn{2}{|c|}{$\begin{array}{c}3.98 \times 10^{6} \\
\left( \pm 3.7 \times 10^{4}\right) \\
\end{array}$} & $\begin{array}{c}1.0 \times 10^{5} \\
\left( \pm 1.72 \times 10^{2}\right) \\
\end{array}$ & $\begin{array}{c}3.2 \times 10^{3} \\
\left( \pm 1.93 \times 10^{1}\right) \\
\end{array}$ \\
\hline S. typhimurium & \multicolumn{2}{|c|}{$\begin{array}{c}2.02 \times 10^{6} \\
\left( \pm 1.4 \times 10^{4}\right)\end{array}$} & $\begin{array}{c}5.6 \times 10^{3} \\
\left( \pm 3.86 \times 10^{2}\right)\end{array}$ & $\begin{array}{c}1.4 \times 10^{4} \\
\left( \pm 1.82 \times 10^{2}\right)\end{array}$ \\
\hline V. cholera & \multicolumn{2}{|c|}{$\begin{array}{c}4.12 \times 10^{6} \\
\left( \pm 3.06 \times 10^{4}\right)\end{array}$} & $\begin{array}{c}2.4 \times 10^{3} \\
\left( \pm 1.57 \times 10^{2}\right) \\
\end{array}$ & $\begin{array}{c}8.0 \times 10^{3} \\
\left( \pm 1.57 \times 10^{3}\right) \\
\end{array}$ \\
\hline
\end{tabular}

All values are average of triplicate samples with the \pm standard deviation $(S D)$ presented in parenthesis.

${ }^{*}$ Presence of target pathogenic bacteria in surface water samples after enrichment steps.

Consequently, the reference strains of the target organisms were spiked into the water samples (Table 2). For surface water sources, the analysis of the water samples resulted in the isolation of presumptive V. cholerae, S. typhimurium and S. dysenteriae by culture-based methods using selective media. These results indicated that $100 \%$ of water samples collected from both surface water of low turbidity (SWL) and surface water of high turbidity (SWH) were contaminated with the target organisms (Table 2). Results obtained from molecular studies confirmed that the selected colonies of presumptive Shigella and Salmonella found in surface water samples were definitely S. dysenteriae and S. typhimurium (Table 3) and those of presumptive Vibrio spp. colonies obtained from the Apies River (SWL) and Hartbeespoort Dam (SWH) water samples, were $V$. cholerae (Table 3). The synthetic water (sterile saline solution) samples were spiked with pure laboratory cultures of each target organism to an average concentration of $6 \log _{10}$ for synthetic water, while groundwater samples were spiked with an average concentration ranging between 3 and $5 \log _{10} \mathrm{CFU} \cdot \mathrm{m} \ell^{-1}$.

Although the bacterial quality of the intake water samples varied during each trial, there was a considerable reduction in bacterial counts after filtering the water samples. In general, the performance of each device depended on the type of organism. No target organisms were detected in both types of surface water sources after filtration by the SIPP filter (Table 4). The removal of maximum concentrations $\left(6 \log _{10}\right.$ to $7 \log _{10}$ units; $>99.99 \%$ removal) of target pathogenic bacteria from synthetic water and groundwater $\left(0.6 \log _{10}\right.$ to $5 \log _{10}$ units; $99 \%$ to $100 \%$ removal) was observed after treating this water source with SIPP (Table 4). These findings are similar to the results of a study done by Van Halem (2006), where the author attempted to determine the highest possible reduction of target pathogenic bacteria by a silver-impregnated clay-pot filter. This author spiked extremely high concentrations of E. coli K12, which resulted in a $7 \log _{10}$ unit reduction. Furthermore, it was noted that, of the five selected devices, SIPP was the only device that achieved total removal of pathogenic bacteria from both groundwater and surface-water samples. This is further supported by published results of faecal coliform and E. coli by these filters, which showed total removal in SIPP (Mwabi et al., 2012). This HWTS therefore consistently produced high-quality drinking water throughout the study (Table 4). The mechanism

\begin{tabular}{|l|c|c|c|c|c|}
\hline \multicolumn{7}{|c|}{ TABLE 3} \\
$\begin{array}{c}\text { Detection of target bacterial pathogens in environmental } \\
\text { water samples by species-specific PCR before filtration }\end{array}$ \\
\hline Bacterium & $\begin{array}{c}\text { Number of } \\
\text { samples }\end{array}$ & \multicolumn{5}{c|}{ Water source } \\
\hline & & SWH & SWL & GWH & GWL \\
\hline S. typhimurium & 5 & 5 & 5 & 0 & 0 \\
\hline S. dysenteriae & 5 & 5 & 5 & 0 & 0 \\
\hline V. cholerae & 5 & 4 & 3 & 0 & 0 \\
\hline
\end{tabular}

by which the SIPP successfully removed pathogenic bacteria was by filtering them out in the fine $0.2 \mu \mathrm{m}$ to $0.5 \mu \mathrm{m}$ micropores created in the clay pot when the clay is kiln-fired during the manufacturing process, burning off the sawdust (Van Halem et al., 2006; Momba et al., 2010b). It is also possible that the silver nano-particles, which are embedded within the clay during manufacturing, contribute to high pathogen-removal efficiency (Michen et al., 2011). Previous studies have reported the effect of $\mathrm{Ag}$ in a water-purification application, irrespective of substrate and have revealed that Ag ions have antiviral and bacteriostatic properties (Nangmenyi et al., 2009; Michen et al., 2012). A study by Momba and co-authors (2010b) revealed that only the Ag-impregnated pot was significantly more effective in removing E. coli, compared to the control pot that had not been impregnated with $\mathrm{AgNO}_{3}$. This superior performance was attributed to the Ag nanoparticles embedded in the micropores.

Prior to filtration, $0.13 \mathrm{mg} \cdot \ell^{-1}$ and $0.07 \mathrm{mg} \cdot \ell^{-1}$ of silver were detected in groundwater and surface water samples, respectively. The amount of silver that leached from the SIPP filter ranged between $0.54 \mathrm{mg} \cdot \ell^{-1}$ and $0.98 \mathrm{mg} \cdot \ell^{-1}$, between $0.22 \mathrm{mg} \cdot \ell^{-1}$ and $0.28 \mathrm{mg} \cdot \ell^{-1}$ and between $0.24 \mathrm{mg} \cdot \ell^{-1}$ and $0.28 \mathrm{mg} \cdot \ell^{-1}$ during filtration of deionised water, groundwater and surface water, respectively. The results obtained from groundwater and surface water showed that the amount of silver leached by SIPP decreased over time (Fig. 6), as the results were much lower than those reported by Momba and co-authors (2010b), who found that $0.5 \mathrm{mg} \cdot \ell^{-1}$ to $0.6 \mathrm{mg} \cdot \ell^{-1}$ of silver was initially leached from the SIPP device (Fig. 6). These results exceeded the WHO (2011) MCL for silver $\left(0.1 \mathrm{mg} \cdot \ell^{-1}\right)$. To date, the only known health consequence of excessive silver intake is a condition known as argyria, which may develop due to improper 


\begin{tabular}{|c|c|c|c|c|c|c|}
\hline \multicolumn{7}{|c|}{$\begin{array}{c}\text { TABLE } 4 \\
\begin{array}{c}\text { Detection and quantification of target pathogenic bacteria in surface water, spiked } \\
\text { synthetic and groundwater samples after filtration }\end{array}\end{array}$} \\
\hline & \multicolumn{2}{|c|}{ V. cholerae } & \multicolumn{2}{|c|}{\begin{tabular}{l|l} 
S. typhimurium & \\
\end{tabular}} & \multicolumn{2}{|c|}{ S. dysenteriae } \\
\hline & $\begin{array}{l}\text { Absence/ } \\
\text { presence }\end{array}$ & $\begin{array}{l}\text { No. of } \\
\text { samples } \\
\text { detected }\end{array}$ & $\begin{array}{l}\text { Absence/ } \\
\text { presence }\end{array}$ & $\begin{array}{c}\text { No. of samples } \\
\text { detected }\end{array}$ & $\begin{array}{l}\text { Absence/ } \\
\text { presence }\end{array}$ & $\begin{array}{c}\text { No. of } \\
\text { samples } \\
\text { detected }\end{array}$ \\
\hline \multicolumn{7}{|c|}{ *Surface water of low turbidity (SWL); $n=18$} \\
\hline SIPP & Absence & 0 & Absence & 0 & Absence & 0 \\
\hline CCF & Absence & 0 & Absence & 0 & Absence & 0 \\
\hline BSF-S & Absence & 0 & Absence & 0 & Absence & 0 \\
\hline BSF-Z & Absence & 0 & Absence & 0 & Absence & 0 \\
\hline $\mathrm{BF}$ & Absence & 0 & Presence & $1(5 \%)$ & Absence & 0 \\
\hline \multicolumn{7}{|c|}{ *Surface water of high turbidity $(\mathrm{SWH}) ; n=18$} \\
\hline SIPP & Absence & 0 & Absence & 0 & Absence & 0 \\
\hline CCF & Absence & 0 & Absence & 0 & Presence & $1(5 \%)$ \\
\hline BSF-S & Absence & 0 & Absence & 0 & Presence & $2(11 \%)$ \\
\hline BSF-Z & Absence & 0 & Absence & 0 & Absence & 0 \\
\hline $\mathrm{BF}$ & Presence & $2(11 \%)$ & Absence & 0 & Presence & $3(17 \%)$ \\
\hline \multicolumn{7}{|c|}{ Average $\log _{10}$ bacterial (percentage $\%$ ) removal of target bacteria from synthetic water; $n=15$} \\
\hline & \multicolumn{2}{|c|}{\begin{tabular}{c|c} 
V. cholerae & \\
\end{tabular}} & \multicolumn{2}{|c|}{ S. typhimurium } & \multicolumn{2}{|c|}{\begin{tabular}{l|l} 
& S. dysenteriae \\
\end{tabular}} \\
\hline SIPP & \multicolumn{2}{|c|}{$>6.6(100)$} & \multicolumn{2}{|c|}{$>6.3(100)$} & \multicolumn{2}{|c|}{$>6.6(100)$} \\
\hline CCF & \multicolumn{2}{|c|}{$3.2(>99.9)$} & \multicolumn{2}{|r|}{$2.2(99.8)$} & \multicolumn{2}{|c|}{$3.6(>99.9)$} \\
\hline BSF-S & \multicolumn{2}{|c|}{$4.8(100)$} & \multicolumn{2}{|r|}{$3.4(>99.9)$} & \multicolumn{2}{|c|}{$3.7(>99.9)$} \\
\hline BSF-Z & \multicolumn{2}{|c|}{$4.6(100)$} & \multicolumn{2}{|r|}{$3.5(>99.9)$} & \multicolumn{2}{|c|}{$3.3(>99.9)$} \\
\hline $\mathrm{BF}$ & \multicolumn{2}{|c|}{\begin{tabular}{l|l}
$1.3(93)$ & \\
\end{tabular}} & \multicolumn{2}{|c|}{$1.7(97)$} & \multicolumn{2}{|c|}{$2.6(99.6)$} \\
\hline \multicolumn{7}{|c|}{$\begin{array}{l}\text { Average } \log _{10}{ }^{\dagger} \text { bacterial (percentage \%) removal of target bacteria from groundwater of low } \\
\text { turbidity (GWL); } n=18\end{array}$} \\
\hline SIPP & \multicolumn{2}{|c|}{$>3.4(100)$} & \multicolumn{2}{|c|}{$>3.8(100)$} & \multicolumn{2}{|c|}{\begin{tabular}{l|l} 
& $>5.0(100)$
\end{tabular}} \\
\hline CCF & $1.6(9$ & & & $2.7(99.7)$ & & $.5(99.5)$ \\
\hline BSF-S & $1.3(9$ & & & $2.2(99.2)$ & & $.5(99.5)$ \\
\hline BSF-Z & $1.4(9$ & & & $2.1(99)$ & & $.7(99.7)$ \\
\hline $\mathrm{BF}$ & 0.97 & 9.9) & & $2.0(99.1)$ & & $.6(99.6)$ \\
\hline $\begin{array}{l}\text { Average } \\
\text { turbidit }\end{array}$ & $\begin{array}{l}{ }^{+} \text {bacterial } \\
\text { JH); } n=18\end{array}$ & ercentage & removal of & target bacteria f & $\mathrm{n}$ ground $\mathbf{w}$ & er of high \\
\hline SIPP & $>3.9$ & $00)$ & & $>4.2(100)$ & & $3.5(100)$ \\
\hline $\mathrm{CCF}$ & $>3.9$ & 00) & & $2.6(99.6)$ & & $1.0(90)$ \\
\hline BSF-S & $>3.9$ & 00) & & $1.3(93)$ & & $0.6(60)$ \\
\hline BSF-Z & $>3.9$ & 00) & & $4.1(100)$ & & $.0(90)$ \\
\hline $\mathrm{BF}$ & $3.7(>s$ & $9.9)$ & & $2.3(99.3)$ & & $0.4(40)$ \\
\hline
\end{tabular}

${ }^{\star}$ The surface water results indicate the absence/presence of target organisms in surface water and show the number of samples detected with organisms, with the percentage (\%) of these samples in brackets. ${ }^{\dagger}$ The log and percentage bacterial removals were calculated from average values of triplicate samples within $1 \mathrm{~h}, 2 \mathrm{~h}$ and $3 \mathrm{~h}$ after filtration.

exposure to chemical forms of the element silver, in which skin and hair become discoloured by silver accumulation. This has been linked to excessive consumption of medications containing silver and not to the use of silver in drinking-water disinfection devices (Lantagne, 2001).

In this study, the CCF removed S. dysenteriae, S. typhimurium and $V$. cholerae, ranging from $1.3 \log _{10}$ to $2.6 \log _{10}$ units (93\% to $99.6 \%$ ), from synthetic water, and from 1 to $3.9 \log _{10}$ units (90\% to $99.9 \%$ ) from groundwater samples. No V. cholerae and S. typhimurium were detected in any of the surface water sources after filtration, while $S$. dysenteriae was detected in $1 / 18(5 \%)$ of the water samples collected from the CCF (Table 4). The findings for synthetic water and groundwater samples spiked with target organisms substantiate the findings reported by Clasen and Boisson (2006) that showed that ceramic candle filters can remove up to $99.99 \%$ or $4 \log _{10}$ units of faecal bacteria. It has been reported that the CCF removes bacteria from water by surface filtration and depth filtration. Some contaminants are trapped on the surface of the ceramic candle, as they are too large to pass through the fine pores, while smaller particles may be trapped within the pore channels of the ceramic candle (CAWST, 2010). These findings are further supported by results that indicated that the CCF removed 1.8 to $3.2 \log _{10}$ (98\% to $99.9 \%$ ) of E. coli (Table 4) (Mwabi et al., 2012).

In general, the average removal of pathogenic bacteria by BSF-S ranged from $3.7 \log _{10}$ to $4.8 \log _{10}$ units ( $>99.99 \%$ removal) for synthetic water and from $0.6 \log _{10}$ to $3.9 \log _{10}$ units $(60 \%$ to $100 \%$ removal) for spiked groundwater samples. Bacterial removal by BSF-Z ranged from $3.3 \log _{10}$ to $4.6 \log _{10}$ units ( $>99.9$ to $100 \%$ removal) for synthetic water and from $1 \log _{10}$ 


\begin{tabular}{|c|c|c|c|c|c|c|}
\hline \multicolumn{7}{|c|}{$\begin{array}{c}\text { TABLE } 5 \\
\text { Statistical analysis to compare the performance of SIPP to the other four HWTS using flow rate and removal of turbidity } \\
\text { and bacteria }\end{array}$} \\
\hline Filter & $\begin{array}{l}\text { Water } \\
\text { source }\end{array}$ & Flow rate & Turbidity & $\begin{array}{l}\text { S. dysenteriae/ } \\
\text { presumptive } \\
\text { Shigella spp. }\end{array}$ & $\begin{array}{l}\text { S. typhimurium/ } \\
\text { presumptive } \\
\text { Salmonella spp. }\end{array}$ & \begin{tabular}{|c|} 
V. cholerae/ \\
presumptive Vibric \\
spp.
\end{tabular} \\
\hline \multirow{4}{*}{ SIPP vs. CCF } & SWL & 0.0002 & 0.0004 & $<0.0001$ & $<0.0001$ & $<0.0001$ \\
\hline & SWH & 0.0611 & $<0.0001$ & $<0.0001$ & $<0.0001$ & $<0.0001$ \\
\hline & GWL & $<0.0001$ & 0.0804 & $<0.0001$ & 0.0001 & 0.0102 \\
\hline & GWH & $<0.0001$ & $<0.0001$ & $<0.0001$ & 1.0000 & 1.0000 \\
\hline \multirow{4}{*}{ SIPP vs. BSF-S } & SWL & $<0.0001$ & 0.5150 & 0.9030 & 0.7290 & $<0.0001$ \\
\hline & $\mathrm{SWH}$ & $<0.0001$ & 0.0050 & 0.0010 & $<0.0001$ & 1.0000 \\
\hline & GWL & 0.0240 & 0.0260 & 0.0170 & 0.9970 & 0.0210 \\
\hline & GWH & $<0.0001$ & $<0.0001$ & 0.6330 & 1.0000 & 1.0000 \\
\hline \multirow{4}{*}{ SIPP vs. BSF-Z } & SWL & $<0.0001$ & 0.8720 & 0.7300 & 0.2270 & $<0.0001$ \\
\hline & SWH & $<0.0001$ & 1.0000 & 1.0000 & 0.2190 & 1.0000 \\
\hline & GWL & $<0.0001$ & 0.9940 & 0.0630 & 0.0950 & 0.3350 \\
\hline & GWH & $<0.0001$ & $<0.0001$ & 0.9610 & 1.0000 & 1.0000 \\
\hline \multirow{4}{*}{ SIPP vs. BF } & SWL & $<0.0001$ & $<0.0001$ & $<0.0001$ & $<0.0001$ & $<0.0001$ \\
\hline & SWH & $<0.0001$ & $<0.0001$ & $<0.0001$ & $<0.0001$ & 1.0000 \\
\hline & GWL & $<0.0001$ & $<0.0001$ & 0.1670 & 0.0020 & $<0.0001$ \\
\hline & GWH & $<0.0001$ & $<0.0001$ & $<0.0001$ & 1.0000 & 1.0000 \\
\hline \multirow{4}{*}{ BSF-S vs. BSF-Z } & SWL & $<0.0001$ & 0.0002 & 0.2253 & 0.4647 & 0.0001 \\
\hline & SWH & $<0.0001$ & $<0.0001$ & $<0.0001$ & $<0.0001$ & 1.0000 \\
\hline & GWL & $<0.0001$ & 0.0267 & 0.5548 & 0.2586 & 0.4393 \\
\hline & GWH & $<0.0001$ & $<0.0001$ & 0.1615 & 1.0000 & 1.0000 \\
\hline
\end{tabular}

to $4.1 \log _{10}$ units (90-100\% removal) for spiked groundwater samples (Table 4). No V. cholerae and S. typhimurium were detected in any of the surface water sources after filtration in both the BSF-S and BSF-Z, while S. dysenteriae was detected in $2 / 18$ (11\%) of the water samples collected from the BSF-S (Table 4). The bacterial removal efficiencies of the biosand filter (BSF) have been reported to range between $60 \%$ and $100 \%$ (Ngai et al., 2007 and Devi et al., 2008). The higher performance of the BSF-S can be attributed to the enhanced straining efficiency through the fine pores formed in the filter media of $0.15 \mathrm{~mm}$ grain size, in combination with the development of the biological layer over time. Elliott and co-authors (2008) have reported that the removal of bacteria by biosand filters at the initial stage occurs by sedimentation and straining. With frequent use of these filters, the removal efficiencies increased, sometimes up to $100 \%$. This is due to the maturation of the biological layer (schmutzdecke) which consists of bacteria, algae, protozoa and invertebrates that enhance bacterial removal. The constant resting water level in the biosand filters was a major factor for the development of the schmutzdecke (Sobsey et al., 2008). It is possible that the natural zeolite used as the filter media in the BSF-Z contributed to the improved performance of this filter. Kallo and Ming (2001) and Misaelides (2011) have previously reported that natural zeolites can remove bacterial pathogens as well as viruses in wastewater. Removal occurs by attachment of microorganisms to the large crystalline surface of the zeolite.

The experimental studies using surface water of high turbidity (SWH) showed that the performance of the BSF-Z was higher than that of the BSF-S in removing pathogens. The BSF-S showed average bacterial removal efficiencies from spiked GWL and GWH of $2.5 \log _{10}$ units (99\%) and $0.6 \log _{10}$ units for S. dysenteriae, $2.2 \log _{10}$ units (99.2\%) and $3.4 \log _{10}$ units (>99\%) for S. typhimurium, and $1.3 \log _{10}$ units $(94.2 \%)$ and $3.9 \log _{10}$ units (100\%) for V. cholerae, respectively (Table 4). The
BSF-Z showed average removals of bacteria from spiked GWL and GWH of $2.7 \log _{10}$ units (99.7\%) and $1.0 \log _{10}$ units (90\%), $2.1 \log _{10}$ units (99\%) and $4.1 \log _{10}$ units (100\%), and $3.9 \log _{10}$ units $(100 \%)$ and $2.4 \log _{10}$ units (99.4\%) for the abovementioned pathogens, respectively (Table 4 ). These findings vindicate reports by Ricke and co-workers (1995), who found that zeolites are able to inhibit the number of viable $S$. typhimurium in water as natural zeolites have antimicrobial properties in soil and water (Uchida et al., 1995). It has also been reported that zeolites can adsorb cholera toxins (Ravin et al., 1997). The bucket filter (BF) exhibited the lowest reductions of the target pathogenic bacteria for all water sources tested, compared to the other HWTS devices, and the growth detected in the enrichment cultures of the target organism was an indicator of this filter's poor performance. Removal of pathogens from synthetic water ranged from $1.7 \log _{10}$ to $3.6 \log _{10}$ units (97\% to $99.9 \%$ ), while removal efficiency from spiked groundwater ranged from $0.4 \log _{10}$ to $3.7 \log _{10}$ units (40\% to $99.99 \%$ ). No V.cholerae and S. dysenteriae were detected in SWL after filtration with the $\mathrm{BF}$ but $S$. typhimurium was detected in 1/18 (5\%) of the water samples collect from the BF. After filtration of SWH by the BF, both V.cholerae and $S$. dysenteriae were detected in 2/18 (11\%) and $3 / 18(17 \%)$, respectively, of the samples collected from this filter (Table 4). The poor bacterial removal efficiency was a consequence of the rapid flow rate of this device. The high flow rate reduced the retention time between filter media and contaminants within the water (Campos et al., 2002). This further explained why turbidity reductions achieved by this filter were poor (14\% to $76 \%$ ) compared to those of the other filters (Table 1). As mentioned earlier, high turbidity levels are associated with high microbiological contamination. Another factor that could be linked to the poor performance of this filter was that there was no resting water level in this device. Hence the filter media always dried out before the next filter run. This 


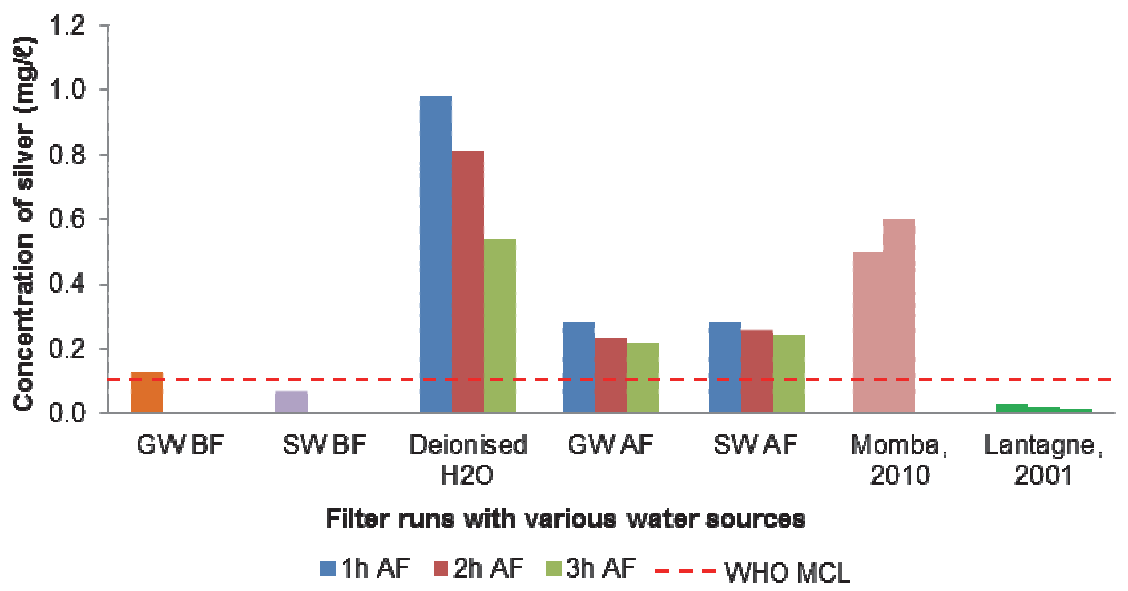

Figure 6

Leaching of silver ions into water filtered by SIPP, GW $B F$ and SW BF represent groundwater and surface water before filtration while GW AF and SW AF represent the groundwater and surface water after filtration (1 h AF, $2 \mathrm{~h} \mathrm{AF}$ and $3 \mathrm{~h}$ AF represent the first, second and third hours after filtration)

means that no biological layer could be established in this filter to enhance its performance. Therefore, bacterial removal in the BF occurred through mechanical trapping only (Elliott et al., 2008; Sobsey et al., 2008).

Statistical analysis of the data showed that the flow rate of the SIPP was significantly lower (Table 5) compared to the flow rates of the remaining four devices $(p<0.05)$. The pores that formed within the SIPP, of $0.2 \mu \mathrm{m}$ to $0.5 \mu \mathrm{m}$ (Momba et al., 2010b), were much finer than the pores formed in the other filters and hence they reduced the flow rate of the SIPP. The flow rate of the CCF was found to be similar to that of the SIPP when filtering SWH $(p>0.05)$. This is due to the fact that the flow rates of these two devices had declined to $<1 \mathrm{l} \cdot \mathrm{h}^{-1}$ at that stage during the treatment of water samples (Fig. 6a-b).

In general, the SIPP turbidity removal efficiency was found to be significantly higher (Table 6) compared to those of the CCF, BSF-S and BF $(p<0.05)$. Statistical data also showed that the SIPP and the BSF-Z performed similarly in reducing turbidity $(p>0.05)$. Based on the fact that the SIPP filter was the only device that consistently produced water that contained 0 CFU. $100 \mathrm{~m}^{-1}$ of bacterial contaminants and had higher turbidity removal efficiency, its performance was compared to those of the other four HWTS (Table 5). Statistical comparison of the devices showed that the SIPP filter had the highest bacterial removal efficiency for the water samples tested. This was expected as $100 \%$ bacterial removal efficiency was consistently achieved by the SIPP $(p>0.05)$, whereas water produced by the remaining four devices still contained some bacterial contaminants (Table 4). Statistical analysis also revealed that the BSF-Z had a significantly superior performance $(p<0.005)$ in removing Salmonella and Shigella spp. from SWH compared to the BSF-S, as well as a higher performance in removing Vibrio spp. from SWL (Table 5). The removal of pathogens by BSF-Z could be occurring via particle straining and it is possible that the zeolite could be enhancing the inactivation of $S$. typhimurium and $V$. cholerae (Uchida et al., 1995; Ravin et al., 1997). It is of great importance that the use of POU household water treatment devices be coupled with safe water storage practices to prevent recontamination of treated water, and rural communities should be advised to keep storage containers clean at all times (Potgieter et al., 2009).

\section{CONCLUSIONS AND RECOMMENDATIONS}

The aim of this study was to find a sustainable and affordable solution for improving drinking water quality in rural areas by evaluating 5 household water-treatment devices that are affordable to rural communities, easy to manufacture and operate, and, most importantly, remove turbidity and pathogens effectively from contaminated water. Based on the findings of this study the use of the silver-impregnated porous pot can be recommended, as it was the only filter that produced safe drinking water, with $<1$ NTU for turbidity level and 0 CFU.100 $\ell^{-1}$ for pathogenic bacteria. To prolong the lifespan of the filter, it is recommended that highly turbid water is pre-treated by settling or straining before filtering in the SIPP. The CCF and biosand filters can also be used due to their high flow rates, but would require additional pre-treatment steps to further disinfect the water produced. The bucket filter (BF) that consistently produced $>100 \mathrm{l} \cdot \mathrm{h}^{-1}$ for the duration of the study showed the poorest performance in terms of removing turbidity and bacterial pathogens. This device is not recommended for household water-treatment purposes, but could be used as a pre-treatment filter for high-turbidity ( $>50 \mathrm{NTU}$ ) water samples. A future investigation can include a study whereby the turbidity and bacterial removal efficiency of the SIPP filter are compared to a non-silver clay pot to confirm whether silver is crucial for superior performance. Further studies should also be conducted on the biosand filter containing zeolite, as it is novel and has shown promising results in removing turbidity and bacterial pathogens. A social acceptance study coupled with a workshop to introduce the devices to rural communities is another approach that can add value to these findings.

\section{ACKNOWLEDGEMENTS}

The authors acknowledge with gratitude the Water Research Commission of South Africa for funding the project and $\mathrm{Mr}$ Maupi Letsoalo for processing the statistical data.

\section{REFERENCES}

APHA (AMERICAN PUBLIC HEALTH ASSOCIATION ) (2005) Standard Methods for the Examination of Water and Wastewater (21 $1^{\text {st }}$ edn.). American Public Health Association; American Water Works Association; Water Environment Federation, Washington DC.

BRÖZEL VS and CLOETE TE (1991) Effect of storage time and temperature on the aerobic plate count and on the community structure of two water samples. Water SA 17 (4) 289-295.

BUZUNIS B (1995) Intermittently Operated Slow Sand Filtration: A New Water Treatment Process. Masters' thesis, Department of Civil Engineering, University of Calgary, Canada. 
BROWN JM (2007) Effectiveness of Ceramic Filtration for Drinking Water Treatment in Cambodia. PhD thesis, Environmental Sciences and Engineering, University of North Carolina, USA.

CAMPOS LC, SU MFJ, GRAHAM NJD and SMITH SR (2002) Biomass development in slow sand filters. Water Res. 36 (18) 4543-4551.

CAWST (CENTRE FOR AFFORDABLE WATER AND SANITATION TECHNOLOGY) (2010) Household Water Treatment and Safe Storage Factsheet. Centre for Affordable Water and Sanitation Technology, Calgary. 15-60.

CLASEN TD (2009) Scaling Up Household Water Treatment Among Low-Income Populations. PhD thesis, London School of Hygiene \& Tropical Medicine, United Kingdom. World Health Organization, Geneva.

CLASEN T and BOISSON S (2006) Household-based ceramic water filters for the treatment of drinking water in disaster response: an assessment of a pilot programme in the Dominican Republic. Water Pract. Technol. 1 (2) 1-9.

DEVI R, ALEMAYEHU E, SINGH V, KUMAR A and MENGISTIE E (2008) Removal of fluoride, arsenic and coliform bacteria by modified homemade filter media from drinking water. Bioresour. Technol. 99 2269-2274.

DWA (DEPARTMENT OF WATER AFFAIRS, SOUTH AFRICA) (2010) Annual Report 2009/10. Department of Water Affairs, Pretoria, South Africa.

DWAF (DEPARTMENT OF WATER AFFAIRS AND FORESTRY, SOUTH AFRICA) (2002) Regulations under Section 9 of the Water Services Act [Act No. 108 of 1997]: Norms \& Standards for Quality Water Services (Explanatory Notes \& Guidelines). Department of Water Affairs and Forestry, Pretoria, South Africa.

ELLIOTT MA, STAUBER CE, KOKSAL F, DIGIANO FA and SOBSEY MD (2008) Reductions of E. coli, echovirus type 12 and bacteriophages in an intermittently operated household-scale slow sand filter. Water Res. 42 (10-11) 2662-2670.

ENVIRONMENT AGENCY, STANDING COMMITTEE OF ANALYSTS (SCA) (2002) The Microbiology of Drinking Water (2002) - Part 10 - Methods for the Isolation of Yersinia, Vibrio and Campylobacter by Selective Enrichment. Blue Book 185. Standing Committee of Analysts (SCA UK), Environment Agency, Rotherham, United Kingdom.

ENVIRONMENT AGENCY, STANDING COMMITTEE OF ANALYSTS (SCA) (2006) The Microbiology of Drinking Water (2006) - Part 9 - Methods for the Isolation and Enumeration of Salmonella and Shigella by Selective Enrichment, Membrane Filtration and Multiple Tube - Most Probable Number Techniques. Blue Book 206, Standing Committee of Analysts (SCA UK), Environment Agency, Rotherham, United Kingdom.

FRANZ A (2004) A Performance Study of Ceramic Candle Filters in Kenya, Including Tests for Coliphage Removal. MEng thesis, Department of Civil and Environmental Engineering, Massachusetts Institute of Technology. Cambridge, Massachusetts, USA.

KALLO D and MING W (2001) Applications of Natural Zeolites in Water and Wastewater Treatment. Mineralogical Society of America, Washington, DC, USA.

KHABO-MMEKOA CMN, MADOROBA E and MOMBA MNB (2010) The prevalence of enteric pathogens in drinking water and its impact on the health of HIV/AIDS individuals in KwaZuluNatal Province, South Africa. Proc. Water Institute of South Africa (WISA), Biennial Conference, 18-22 April 2010, Durban, South Africa.

KONG RYC, LEE SKY, LAW TWF, LAW SHW and WU RSS (2002) Rapid detection of six types of bacterial pathogens in marine waters by multiplex PCR. Water Res. 36 2802-2812.

LANTAGNE DS (2001) Investigation of the Potters for Peace colloidal silver-impregnated ceramic filter: Intrinsic effectiveness and field performance in rural Nicaragua. Alethia Environmental, Allston, Massachusetts.

LEA M (2008) Biological sand filters: Low-cost UNIT 1G.1 bioremediation technique for production of clean drinking water. Curr. Protoc. Microbiol. 1G.1.1-1G.1.28.
LOW J (2002) Appropriate Microbial Indicator Tests for Drinking Water in Developing Countries and Assessment of Ceramic Water Filters. MEng thesis, Department of Civil and Environmental Engineering, Massachusetts Institute of Technology. Cambridge, Massachusetts, USA.

MAHLANGU TO, MPENYANA-MONYATSI L, MAMBA BB and MOMBA MNB (2011) A simplified cost-effective biosand filter (BSFZ) for removal of chemical contaminants from water. J. Chem. Eng. Mater. Sci. 2 (10) 156-167.

MAHLANGU TO, MAMBA BB and MOMBA MNB (2012) A comparative assessment of chemical contaminant removal by three household water treatment filters. Water SA 38 (1) 39-47.

MICHEN B, DIATTA A, FRITSCH J, ANEZIRIS CG and GRAULE T (2011) Removal of colloidal particles in ceramic depth filters based on diatomaceous earth. Sep. Purif. Technol. 81 77-87.

MICHEN B, MEDER F, RUST A, FRITSCH J, ANEZIRIS C and GRAULE T (2012) Virus removal in ceramic depth filters based on Diatomaceous earth. Environ. Sci. Technol. 46 (2) 1170-1177.

MISAELIDES P (2011) Application of natural zeolites in environmental remediation: a short review. Micropor. Mesopor. Mater. 144 $15-18$.

MOL A (2001) The success of household filtration. Waterlines 20 (1) 27-30.

MOMBA MNB and NOTSHE TL (2003) the effect of long storage and household containers on the microbiological quality of drinking water in rural communities of South Africa. J. Water Supply Res. Technol. 52 (1) 67-76.

MOMBA MNB, MAKALA N, TYAFA Z, BROUCKAERT BM, BUCKLEY CA and THOMPSON PA (2004) Improving the efficiency and sustainability of disinfection at a small rural water treatment plant. Water SA 30 (5) 69-74.

MOMBA MNB, MALAKATE VK and THERON J (2006) Abundance of pathogenic Escherichia coli, Salmonella typhimurium and Vibrio cholerae in Nkonkobe drinking water sources. J. Water Health. 4 289-296.

MOMBA MNB, MADOROBA E and OBI CL (2010a) Apparent impact of enteric pathogens in drinking water and implications for the relentless saga of HIV/AIDS in South Africa. In: MéndezVilas A (ed.) Current Research, Technology and Education Topic in Applied Microbiology and Microbial Biotechnology. Formatex Microbiological Series No. 2. Formatex, Badajoz, Spain. 615-625.

MOMBA MNB, OFFRINGA G, NAMENI G and BROUCKAERT B (2010b) Development of a Prototype Nanotechnology-Based Clay Filter Pot to Purify Water for Drinking and Cooking in Rural Homes. WRC Report No. KV 244/10. Water Research Commission, Pretoria. 27-32.

MURPHY HM, McBEAN EA and FARAHBAKHSH K (2009) Appropriate technology - a comprehensive approach for water and sanitation in the developing world. Technol. Soc. 31 158-167.

MURCOTT S (2006) Implementation, critical factors and challenges to scale-up of household drinking water treatment and safe storage systems. Background paper on household water treatment and safe storage (HWTS). Proc. Electronic Conference Hosted by USAID/ Hygiene Improvement Project (HIP), 12-22 May 2006. 1-39.

MWABI JK, ADEYEMO FE, MAHLANGU TO, MAMBA BB, BROUCKAERT BM, SWARTZ CD, OFFRINGA G, MPENYANAMONYATSI L and MOMBA MNB (2011) Household water treatment systems: a solution to the production of safe drinking water by the low-income communities of Southern Africa. J. Phys. Chem. Earth 36 (14-15) 1120-1128.

MWABI JK, MAMBA BB and MOMBA MNB (2012) Removal of Escherichia coli and faecal coliforms from surface water and groundwater by HWTS: A sustainable solution for improving water quality in rural communities of the SADC region. Int. J. Environ. Res. Public Health 9 (1) 139-170.

NANGMENYI G, XAO W, MEHRABI S, MINTZ E and ECONOMY J (2009) Bactericidal activity of Ag nanoparticle-impregnated fibreglass for water disinfection. J. Water Health 7 657-663.

NGAI T MURCOTT S and SHRESTHA R (2004) Kanchan Arsenic Filter (KAF) - Research and Implementation of an Appropriate Drinking Water Solution for Rural Nepal. Cambridge, MA and 
Kathmandu: Massachusetts Institute of Technology and ENPHO, Nepal. URL: http://web.mit.edu/watasan/Docs (Accessed 23 August 2011).

NGAI TKK, SHRESTHA RR, DANGOL B, MAHARJAN M and MURCOTT SE (2007) Design for sustainable development - household drinking water filter for arsenic and pathogen treatment in Nepal. J. Environ. Sci. Health, Part A: Environ. Sci. Eng. 42 (12) 1879-1888.

OBI CL and BESSONG PO (2002) Diarrhoeagenic bacterial pathogens in HIV-positive patients with diarrhoea in rural communities of Limpopo Province, South Africa. J. Health Popul. Nutr. 20 (3) $230-234$

OBI CL, MOMBA MNB, SAMIE A, IGUMBOR JO, GREEN E and MUSIE E (2007) Microbiological, physicochemical and management parameters impinging on the efficiency of small water treatment plants in the Limpopo and Mpumalanga Provinces of South Africa. Water SA 33 (2) 1-9.

POTGIETER N, KOEKEMOER R and JAGALS P (2007) A pilot assessment of water, sanitation, hygiene and homebased care services for people living with HIV/AIDS in rural and peri-urban communities in South Africa. Water Sci. Technol. 56 (5) 125-131.

POTGIETER N, BECKER PJ and EHLERS MM (2009) Evaluation of the CDC safe water-storage intervention to improve the microbiological quality of point-of-use drinking water in rural communities in South Africa. Water SA 35 (4) 1-12.

RAVIN J, CLARK K, WOODE GN, SARR AB and PHILLIPS TD (1997) Adsorption of cholera and heat-labile Escherichia coli enterotoxins by various adsorbents: An in vitro study. J. Food Protect. 60 358-362.

RICKE SC, PILLAI SD, WIDMER KW and HA SD (1995) Clinoptilolite compounds as a retardant of bacterial pathogen survival in agricultural soils and water. Bioresour. Technol. 53 1-6.

SABS (SOUTH AFRICAN BUREAU OF STANDARDS) (2011) South African National Standard, SANS 241, 2011. Drinking Water Specification: Part 1: Microbiological, physical, aesthetic and chemical determinants. South African Bureau of Standards (SABS), Pretoria.

SOBSEY MD (2002) Managing Water in the Home: Accelerated Gains from Improved Water Supply. World Health Organization, Geneva, Switzerland.

SOBSEY MD, STAUBER CE, CASANOVA LM, BROWN JM and ELLIOTT MA (2008) Point of use household drinking water filtration: a practical, effective solution for providing sustained access to safe drinking water in the developing world. Environ. Sci. Technol. 42 4261-4267.

THIEM VD, SETHABUTR O, VON SEIDLEIN L, VAN TUNG T, CANH DG, CHIEN BT, THO LE, LEE H, HOUNG HS, HALE TL, CLEMENS JD, MASONC and TRACH DD (2004) Detection of Shigella by a PCR assay targeting the ipaH gene suggests increased prevalence of shigellosis in Nha Trang, Vietnam. J. Clin. Microbiol. 42 (5) 2031-2035.

UCHIDA T, MARN N, FURUHATA M, FUJINO A, MURAMOTO S, ISHIBASHI A, KOSHIBA K, SHIBA T, KIKUCHI T, PATZER JF, YAO SJ and WOLFSON SK (1995) Anti-bacterial zeolite balloon catheter and its potential for urinary tract infection control. ASAIO J. 41 221-226.

VAN HALEM D (2006) Ceramic Silver-Impregnated Pot Filters for Household Drinking Water Treatment in Developing Countries. MSc thesis in civil engineering, Delft University of Technology, The Netherlands.

VAN HALEM DS, VAN DER LAAN H, HEIJMAN SGJ, VAN DIJK JC and AMY GL (2009) Assessing the sustainability of the silverimpregnated ceramic pot filter for low-cost household drinking water treatment. Phys. Chem. Earth. 34 36-42.

WHO (WORLD HEALTH ORGANIZATION) (2011) WHO Guidelines for Drinking Water Quality ( $4^{\text {th }}$ edn.). World Health Organization: Geneva, Switzerland.

WHO/UNICEF (WORLD HEALTH ORGANIZATION/UNITED NATIONS CHILDREN'S FUND) (2008) A snapshot of drinking water and sanitation in Africa. Joint Monitoring Programme. WHO, Geneva and New York.

WHO/UNICEF (WORLD HEALTH ORGANIZATION/UNITED NATIONS CHILDREN'S FUND) (2010) Progress on sanitation and drinking water: 2010 update. Mortality data. Joint Monitoring Programme on Water Supply and Sanitation. WHO, Geneva and New York. 